\title{
Perbandingan Nilai Nutrisi pada Beberapa Spesies Tumbuhan Akuatik Perairan Rawa Pening
}

\section{The Comparison Nutrition Facts of Aquatic Plants Rawa Pening Lake}

\author{
Munifatul Izzati \\ Departemen Biologi, Fakultas Sains dan Matematika, Universitas Diponegoro \\ Jl. Prof. Soedarto, SH, Tembalang, Semarang \\ Email : Munifatul_Izzati@yahoo.com
}

Diterima 30 Mei 2016 / Disetujui 11 Agustus 2016

\begin{abstract}
ABSTRAK
Tumbuhan akuatik sering tumbuh melimpah di ekosistem perairan. Pertumbuhannya yang cepat menyebabkan pendominasian di kawasan perairan. Oleh karena itu diperlukan upaya untuk memanfaatkannya, sehingga populasinya dapat dikendalikan. Penelitian ini bertujuan untuk menguji nilai nutrisi dari beberapa spesies tumbuhan akuatik ditinjau dari berat kering, kadar protein, lemak dan karbohidrat. Sebanyak 9 spesies tumbuhan akuatik dikoleksi dari beberapa titik, di perairan Rawa Pening, Jawa Tengah. Spesies tumbuhan yang sama dicampur, dikeringkan, dan ditumbuk hingga halus. Tepung yang dihasilkan selanjutnya dianalisis berat kering, kandungan protein, lemak dan karbohidratnya melalui analisis proksimat secara duplo. Data yang diperoleh dibuat reratanya dan disajikan dalam grafik. Hasil penelitian menunjukkan bahwa berat kering tertinggi dihasilkan oleh Myriophyllum siberesum, kandungan protein tertinggi dihasilkan oleh Ceratophyllum demersum, kandungan lemak tertinggi dihasilkan oleh Pistia stratiotes, sedangkan kandungan karbohidrat tertinggi dihasilkan oleh Salvinia molesta. Tumbuhan akuatik dengan kandungan protein, lemak dan karbohidrat yang tinggi mempunyai potensi untuk dikembangkan menjadi pakan.
\end{abstract}

Kata kunci: tumbuhan akuatik, protein, lemak, karbohidrat

\begin{abstract}
The abundant of aquatic plants in freshwater ecosystem had led to its dominant population. Analizing their nutritive value is necessary to assist in controlling their high population. The aim of this study is to investigate their dry matter, protein, fat and carbohydrate content. If aquatic plants have high content of protein, fat and carbohydrate, it is indicted that these plants are potential to be developed for feed industry. Approximately 9 species of aquatic plants were collected from several location in Rawa Pening lake. The collected plants with the same species were mixed, transported to the laboratorium and dried under the sun. The dried sample was then milled into powder and be analyzed their dry matter, protein, fat and carbohydrate content. Results indicated that Myriophyllum siberesum has the highest persentage of dry matter, Ceratophyllum demersum has the highest protein content, Pistia stratiotes has the highest of fat content, while Salvinia molesta has the hihgest carbohydrate content. Species with high content of protein, fat and carbohydrat were the most potential to be developed for feed industry.
\end{abstract}

Keywords: Aquatic plants, protein, fat, carbohydrate

\section{PENDAHULUAN}

Tumbuhan akuatik mempunyai peranan penting dalam ekosistem perairan, terutama dalam menyediakan makanan dan merupakan habitat hidup bagi berbagai organisme. Dalam ekosistem perairan, tumbuhan akuatik juga berperan dalam menstabilkan sedimen, meningkatkan kejernihan air dan menambah keanekaraman hayati dalam perairan (Madsen, 2014). Kandungan gizi pada berbagai tumbuhan akuatik mulai menarik minat bagi beberapa peneliti, mengingat peranan pentingnya sebagai pensuplai paka alami bagi invertebrata, insekta dan fauna akuatik lainnya 
(Akmal dkk., 2014). Anon (1984), telah meneliti kandungan gizi pada beberapa tumbuhan akuatik dalam rangka dimanfaatkan untuk pakan ternak. Hasil penemuannya menunjukkan bahwa tumbuhan akuatik mempunyai kandungan kimia yang bervariasi, tergantung pada jenis, musim dan lokasinya. Pemanfaatan tumbuhan akuatik untuk pakan ternak terbukti menghasilkan air susu lebih banyak dibanding dengan ternak yang diberi pakan meggunakan jerami saja (Shah, dkk., 2010).

Penelitian ini bertujuan untuk menganalisis kandungan karbohidrat, protein dan lemak pada beberapa spesies tumbuhan akuatik yang berasal dari perairan tawar. Analisis kandungan protein, lemak dan karbohidrat pada penelitian ini bertujuan untuk mengetahui kualitas internal dari makroalga yang akan digunakan sebagai "forcing function" atau faktor pemicu. Semakin tinggi kandungan protein dan lemak, makroalga akan semakin tinggi nilainya untuk digunakan sebagai forcing function. Hal ini disebabkan karena makroalga yang akan digunakan dapat digali potensi ekonominya sehingga akan lebih meningkatkan pendapatan petani ikan.

\section{METODE PENELITIAN}

Penelitian ini dimulai dengan melakukan survey di daerah sampling, yaitu di danau Rawa Pening, Ambarawa, Jawa Tengah. Pemilihan lokasi ini dilakukan karena di danau tersebut sudah dipenuhi oleh tumbuha akuatik yang sangat padat, sehingga menimbulkan gangguan yang sangat signifikan.

Berdasarkan pada kepadatan tumbuhan akuatik yang ada di perairan tersebut, selanjutnya dipilih sebanyak 9 spesies tumbuhan air tawar, yaitu: Hydrilla verticillata, Ceratophyllum demersum, Salvinia molesta, Eichornia crassipes, Myriophyllum siberesum, Pistia stratioiotes, Elodea Canadensis, Chara vulgaris dan Lemna minor.

Setiap spesies tumbuhan akuatik tersebut diambil sebanyak kurang lebih 5 kantong plastik, kemudian dibawa ke laboratorium untuk dilakukan analisis proksimat. Di Laboratorium, tumbuhan tersebut dibersihkan dari kotoran yang menempel, kemudian di jemur hingga kering dibawah sinar maatahari hingga mencapai berat yang konstan. Setelah itu dilakukan analisis proksimat untuk mengetahui kandungan air, kadar abu, kandungan protein, lemak dan karbohidrat. Analisis proksimat dilakukan secara duplo dan hasil yang diperoleh dirata rata.

\section{HASIL DAN PEMBAHASAN}

\section{Berat Kering Tumbuhan Akuatik}

Berat kering merupakan indikator penting untuk mengukur komposisi kimia suatu tumbuhan, karena merupakan hasil bersih dari proses asimilasi (McDonald dkk., 1996). Hasil penelitian ini menunjukkan bahwa berat kering pada tumbuhan akuatik berkisar antara 3,50\% sampai dengan $13,70 \%$.

Hasil pengamatan terhadap berat kering pada tumbuhan akuatik dari perairan Rawa Pening menunjukkan bahwa berat kering tertinggi dihasilkan oleh tumbuhan Myriophyllum siberesum, sementara itu, berat kering terrendah dihasilkan oleh tumbuhan Elodea canadensis (Grafik 1).

Berat kering suatu tumbuhan banyak dipengaruhi diantaranya oleh ketersediaan mineral dan nutrien di daerah rhizosfera dan aliran nutrien masuk kedalam akar. Spesies ini hidup tenggelam di dalam badan air. Kecepatan fotosintesis Myriophyllum relatif besar dibandingkan dengan spesies tumbuhan akuatik yang lain (Madsen, dkk., 1991). Menurut Arshid dan Wani (2013), sebagian besar berat kering yang dihasilkan oleh proses photosynthesis pada Myriophyllum diakumulasikan di daerah daun, sementara bagian yang berada dibawah sedimen mempunyai akumulasi berat kering yang paling rendah. Proses fisiologis ini menyebabkan tingginya berat kering pada Myriophyllum dibandingkan dengan tumbuhan akuatik perairan tawar lainnya. 


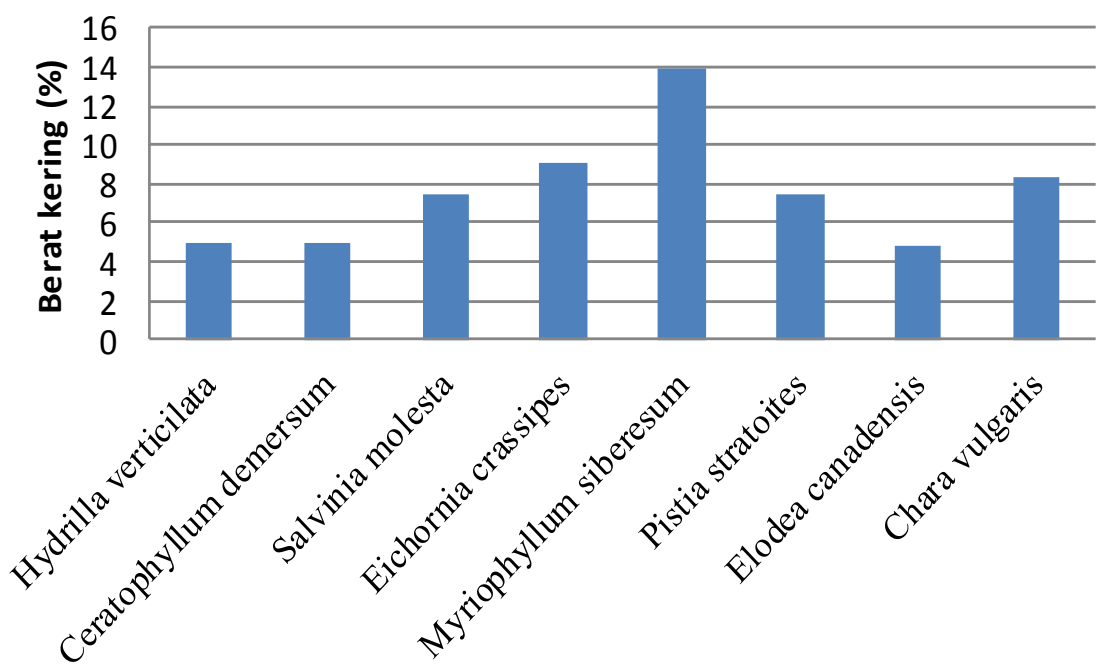

Gambar 1. Perbedaan Berat Kering pada Beberapa Tumbuhan Akuatik Perairan Tawar

\section{Kadar Protein Tumbuhan Akuatik}

Hasil penelitian ini menunjukkan bahwa kandungan protein dari beberapa spesies tumbuhan akuatik dari perairan Rawa Pening, berkisar antara $5,12 \%$ sampai dengan $23,44 \%$ dari berat kering. Hasil penelitian terhadap kandungan protein dari 9 spesies tumbuhan akuatik yang diambil dari perairan danau Rawa Pening telah dirangkum pada gambar 2.

Kandungan protein pada makroalga air tawar paling tinggi adalah yang terkandung pada
Ceratophyllum Kandungan protein pada tanaman ini mencapai lebih dari 23\%.

Kandungan protein tertinggi kedua adalah pada Pistia stratiotes dengan kandungan protein mencapai lebih dari $20 \%$. Kandungan protein pada Hydrilla verticillata cukup tinggi juga yaitu $18 \%$. Lemna minor dan Chara vulgaris mempunyai kandungan protein sekitar $17 \%$. Myrriophullum, Salvinia dan Oxalis mempunyai kandungan protein berkisar antara $10 \%$ hingga $15 \%$.

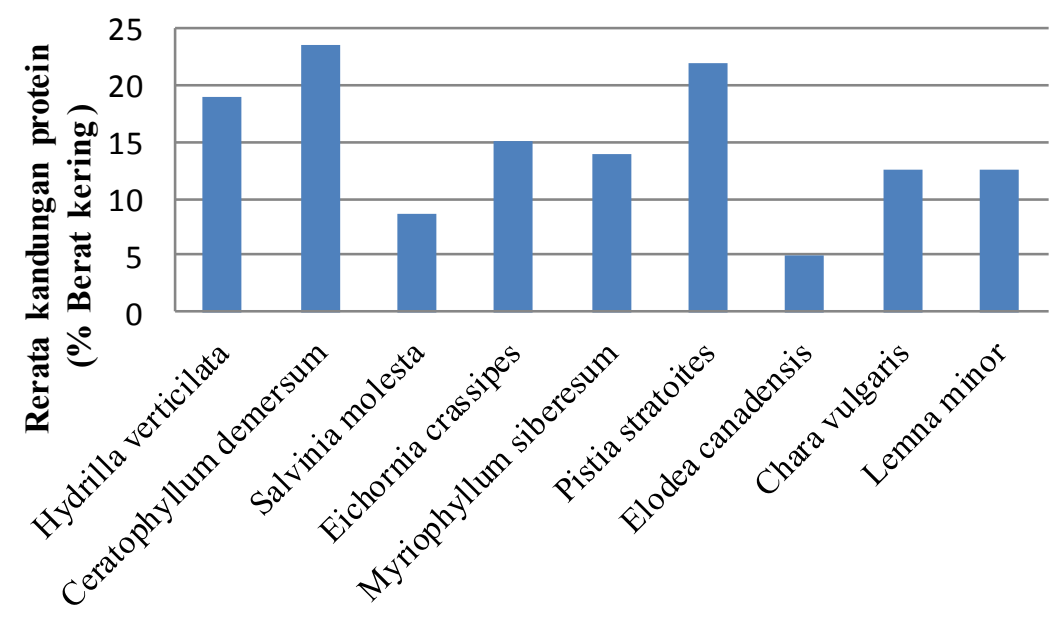

Gambar 2. Perbedaan Kadar Protein pada Beberapa Tumbuhan Akuatik Perairan Tawar 
Kandungan protein pada tumbuhan akuatik, terutama di Indonesia belum banyak diteliti. Boyd (1968), menyatakan bahwa tumbuhan akuatik merupakan sumber protein yang potensial untuk dikembangkan. Pesatnya pertumbuhan dan padatnya populasi tumbuhan akuatik di lahan perairan menjadikan pertimbangan penting yang mendasari dilakukannya penelitian ini. Kandungan protein pada tumbuhan akuatik dapat digunakan sebagai bahan dasar untuk sumber pangan manusia (Dewanji, 1993), ataupun sebagai sumber pakan (Akmal, dkk., 2014). Tingginya kandungan protein pada Ceratophyllum ini memacu penelitian untuk memanfaatkannya sebagai sumber protein untuk pakan ikan herbovora, Baronang (Laining dkk., 2016). Rather dan Nazir (2015), menganjurkan, karena tingginya kandungan protein pada tumbuhan akuatik ini, sehingga bisa digunakan sebagai sumber pakan. Dari hasil penelitian ini dapat disimpulkan bahwa ditinjau dari kandungan protein dalam makroalga, maka tumbuhan air tawar yang mempunyai nilai komersial paling tinggi adalah Ceratophyllum dimersum.

Hasil pengamatan terhadap kandungan gizi pada beberapa jenis tumbuhan air menunjukkan bahwa pemanfaatan tumbuhan air sebagai sumber pangan dan pakan adalah sangat prospektif. Hal ini dapat dilihat dari kandungan protein yang tinggi pada beberapa jenis tumbuhan air. Dengan ditemukannya jenis tumbuhan air yang mengandung protein cukup tinggi, diharapkan dapat digunakan untuk menggantikan peranan kedelai dalam mensuplai protein nabati. Protein nabati ini dapat digunakan untuk kebutuhan pangan manusia maupun dapat digunakan untuk pakan bagi hewan ternak.

\section{Kadar Lemak Tumbuhan Akuatik}

Potensi gizi lainnya yang dapat dianalisis adalah kandungan lemak pada setiap jenis tumbuhan air. Kandungan lemak atau minyak pada tumbuhan dapat digunakan dan dikembangkan menjadi biofuel (Olisegun dan Phillip, 2016). Hasil penelitian ini menunjukkan rerata kandungan lemak pada tumbuhan akuatik yang diteliti berkisar antara 0,57\% s.d 6,30\% dari berat kering Kandungan lemak ini relatif lebih tinggi. Hasil penelitian oleh Mutzar dkk (1978), menunjukkan kisaran kandungan lemak pada beberapa tumbuhan akuatik yang lebih rendah, yaitu antara 1,575\% s/d 4,74\%. Hasil penelitian menunjukkan bahwa kandungan lemak paling tinggi adalah Pistia stratiotes, dengan kadar lemak sekitar 6\%. Diikuti oleh Myrriophyllum dan Chara vulgaris masing masing sebanyak $3.78 \%$ dan $2.78 \%$. Jenis makroalga yang lain mempunyai kandungan lemak kurang dari $2 \%$ (gambar 3 ).

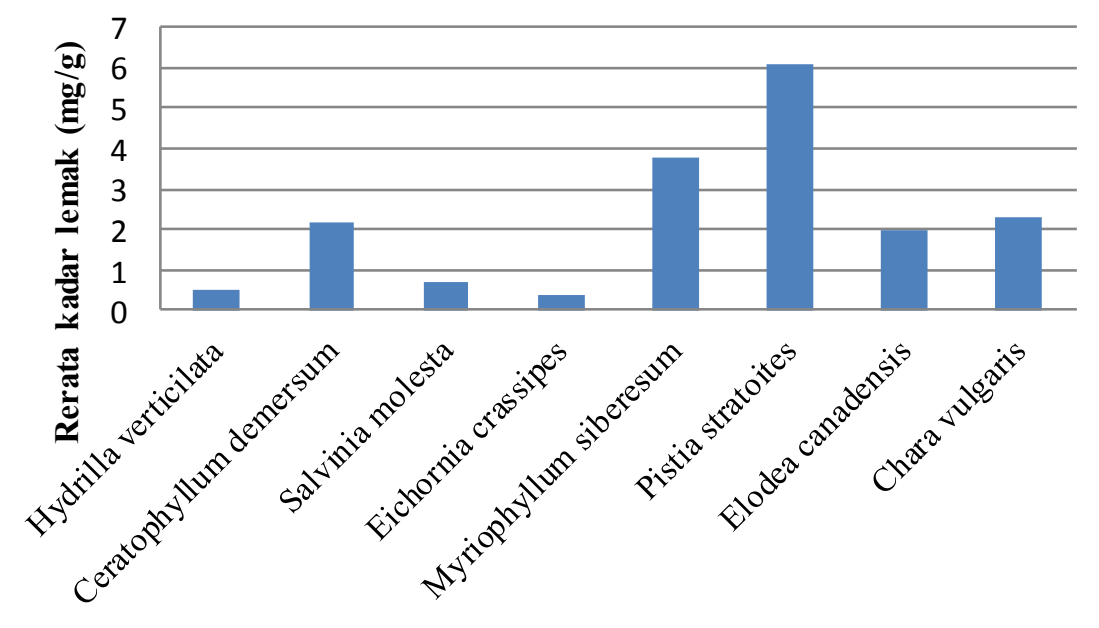

Gambar 3. Perbedaan Kadar Lemak pada Beberapa Tumbuhan Akuatik Perairan Tawar 
Perbedaan komposisi kimia pada tumbuhan akuatik ini bervariasi tergantung pada tingkat kesuburan perairan dan juga usia perairan tempat hidupnya (Muztar, dkk., 1978). Kandungan lemak dan karbohidrat merupakan bahan organik yang mudah di transfer ke konsumen dalam perairan (Esteves dan Suzuki 2010). Selanjutnya dijelaskan bahwa musim sangat berpengaruh terhadap kandungan karbohidrat maupun lemak. Pada Ceratophyllum demersum, peningkatan kandungan bahan organik ini bisa mencapai 5 kali lipat.

\section{Kadar Karbohidrat Tumbuhan Akuatik}

Pengamatan terhadap kandung karbohidrat dari tumbuhan akuatik yang diteliti mempunyai kisara antara 20,2 s/d 47,10\% berat kering. Penelitian oleh (Hasan, 2009) ) menunjukkan kandungan karbohidrat pada beberapa tumbuhan akuatik berkisar antara $10,2 \%$ s/d $\quad 20,4 \%$. Kandungan karbohidrat tertinggi dari penelitian ini dihasilkan oleh Salvinia molesta, berturut urut diikuti oleh Hydrilla verticillata, Ceratophyllum demersum, Lemna minor, Pistia stratiotes, Chara vulgaris, Myriophyllum seberesum, Eichornia crassipes dan Elodea canadensis (Gambar 4).

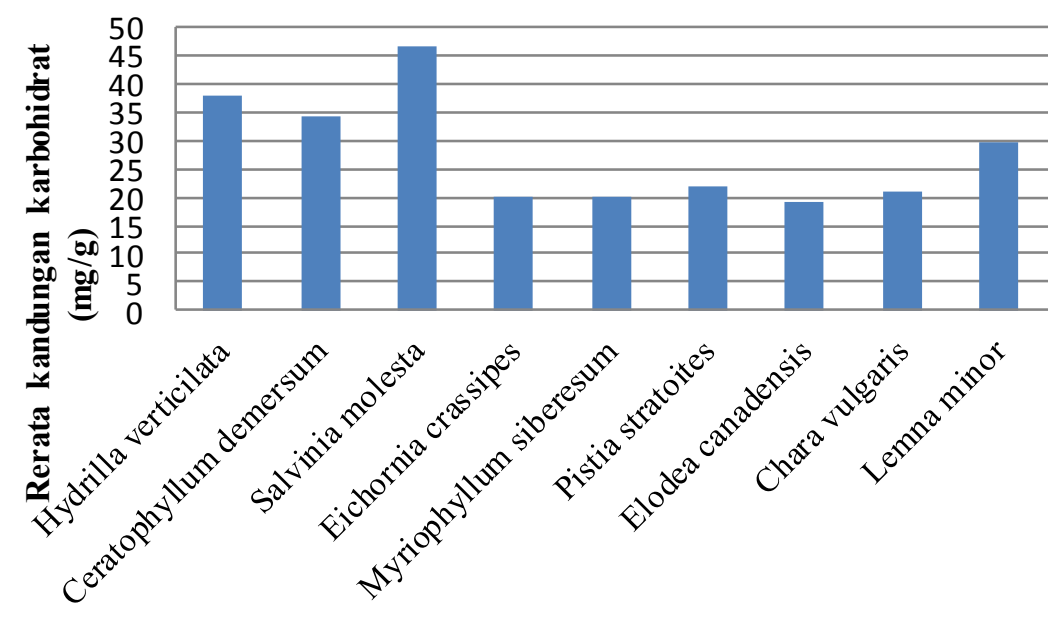

Gambar 4. Perbedaan Kadar Karbohidrat pada Beberapa Tumbuhan Akuatik Perairan Tawar

Menurut Singh dkk., (1967), kandungan karbohidrat yang relatif tinggi pada tumbuhan akuatik menyebabkan beberapa spesies ini disukai oleh herbivora. Tumbuhan akuatik ini juga digunakan untuk pakan bagi ikan karper (Hasan,2009). Penambahan pakan menggunakan Eichornia crassipes telah terbukti dapat meningkatkan pertumbuhan ikan (Saha dan Ray, 2011).

\section{SIMPULAN}

Dari hasil penelitian ini dapat disimpulkan bahwa berat kering, kandungan protein, lemak dan karbohidrat pada tumbuhan air bervariasi, tergantung pada spesiesnya. Secara umum, tumbuhan akuatik air tawar dari perairan Rawa
Pening ini mempunyai kandungan protein dan karbohidrat yang cukup tinggi. Berat kering tertinggi dihasilkan oleh tumbuhan Myriophyllum siberesum, kandungan protein tertinggi oleh Ceratophyllum demersum, kandaungan lemak tertinggi dihasilkan oleh Pistia sratiotes dan kandungan karbohidrat tertinggi dihasilkan oleh Salvinia molesta. Tumbuhan akuatik dengan kandungan protein, lemak dan karbohidrat yang tinggi berpotensi untuk dikembangkan lebih lanjut menjadi pakan sehingga dapat ditingkatkan nilai komersialnya

\section{DAFTAR PUSTAKA}

Akmal, M; M.H. Rehman, S. Ullah, N. Younus, K.J. khan dan M. Qayyum (2014): Nutritive value of Aquatic Plants of Head 
Baloki on Ravi river, Pakistan. International Journal of Bioscience (IJB) vol 4, no 10. Pp 115-122.

Anon. 1984. Making Aquatic Weed Useful : Some Perspective For Developing Countries. National Academy of Sciences, Washington, D.C., 175

Arshid, S and A.A. Wani (2013): Phenotypic plasticity, clonal architecture and biomass partitioning Myriophyllum spicatum L. Across different lentic and lotic ecosystems of Kashmir. African Journal of Biotechnology.

Byod, C.E (1986) : Fresh Water Plants: Potential Sources of Protein. Economic Botany, 22: 359-368

Esteves, B.S. dan M.S. Suzuki (2010): Limnological variables and nutritional content of submerged aquatic macrophytes in a tropical lagoon, Acta Limnologica Brasiliensia, 2010, vol. 22, no. 2, p. 187198

Dewanji, Anjana (1993) : Amino Acid Composition of Leaf Protein Extracted From Some Aquatic Weeds. J.Agriculture Food Chem. 41:1232-1236

Laining, A., U. Usman, R. Shah (2016) : Aquatic Weeds Ceratiophyllum sp., as a Dietary Protein Sources. Its Effect on Growth and Fillet Amino Acid Profile of Rabbitfish, Siganus guttatus. AACL Bioflux, Vol 9. Issue 2, 352-359

Madsen, J.D. (2014): Impact of Invasive Aquatic Plants on Aquatic Botany. Dalam Biology and Aquatic Ecosystem Restoration Foundatio (AERF). Missisippi State University. Missisippi, USA. of Myriophullum spicatum and six submerged aquatic macrophyte species native to lake George. New York. Freshwater Biology, Vol 26. Issue 2. Pp $232-240$.

McDonald, A.J.S., T. Ericsson dan C.M. Larsson (1996): Plant Nutrition, Dry matter gain and Partitioning at the whole Plant Level.
Journal of Experimental Botany, Vol 47, Special Isue, pp 1245-1253.

Muztar,A,J,. S,J. Slinger, dan H,J, Burton: Chemtcal Compositton of Aquattc Macrophytes Investigation of Organic Constituents and Nutritional Potential. Canadian Journal of Plant Science. $56: 829-841$

Olisegun. A.A. dan O.A Phillip (2014): Ekstraction of Oil from Microalgae and quatic Plants Harvested from Fish Rear ing Structures. Transnational Journal of $\mathrm{tS}$ cience and Technology, Vol 3, No 2. ISSN 1857-804,

Rather, Z.A. dan R. Nazir (2015): Biochemical composition of selected Macrophyte of Dal Lake, Kashmir. Himalaya. Ecosystem \& Ecography. 2015, 5:1.

Saha, S. Dan A.K Ray (2011): Evaluation of Nutritive Value of Water Hyacinth (Eichornia crassipes) Leaf Meal in Compound Diets for Rohu, Labeo rohita, Fingerlings after Fermeentation with two Bacterial Strain Isolated from Fish Gut. Turkish Journal of Fisheries and Aquatic Sciences 11: 199-207.

Shah, dkk. (2010): A Study of Nutritional Potential of Aquatic plants. Online Veterinary Journal, Vol 5, No 1, Article 53.

Singh, S.B., Sukumaran, K.K., Chakrabarti. P.C. \& Bagchi, M.M. (1967): Observations on the efficacy of grass carp, Ctenopharyngodon idella (Val.) in controlling and utilizing aquatic weeds in ponds in India. Proceedings of the Indo-Pacific Fisheries Council, 12: 220-235 